\title{
PENGARUH PEMBERIAN BUNGKIL INTI KELAPA SAWIT YANG DIFERMENTASI MENGGUNAKAN ISOLAT SELULOLITIK DARI BELALANG KEMBARA PADA PAKAN TERHADAP PENAMPILAN PRODUKSI PUYUH JANTAN
}

\section{THE EFFECTS OF PALM KERNEL CAKE UTILIZATION IN THE DIET THAT FERMENTED BY CELLULOLITYC BACTERIA ISOLATED FROM GRASSHOPER ON PERFORMANCE OF MALE JAPANESE QUAIL}

\author{
Arif Pranata* \\ PT Padma Karya Prima, Divisi Breeding Farm, Jakarta Barat, 11480
}

Submitted: 27 March 2014, Accepted: 2 January 2015

\section{INTISARI}

Penelitian bertujuan untuk mengetahui pengaruh pemberian bungkil kelapa sawit yang difermentasi menggunakan isolat selulolitik dari belalang terhadap penampilan produksi puyuh jantan. Sebanyak 210 ekor puyuh jantan berumur 14 hari, dibagi dalam 7 perlakuan yang setiap perlakuannya terdiri dari 3 ulangan dan setiap ulangan terdiri dari 10 ekor puyuh. Kelompok perlakuannya yaitu: kelompok tanpa pemberian bungkil inti kelapa sawit (kontrol; K), kelompok perlakuan dengan pemberian bungkil inti kelapa sawit (BIKS) sebanyak 10, 20, dan 30\% dari total ransum, serta kelompok dengan pemberian bungkil inti kelapa sawit fermentasi (BIKSF) sebanyak 10, 20, dan 30\% dari total ransum. Pengambilan data dilakukan setiap minggu. Parameter yang diamati adalah berat badan akhir, persentase karkas, konsumsi pakan, dan konversi pakan. Data yang diperoleh dianalisis menggunakan Rancangan Acak Lengkap Pola Searah dan apabila hasilnya berbeda nyata dilanjutkan dengan uji Duncan's New Multiple Range Test. Hasil analisis variansi menunjukkan pemberian bungkil inti kelapa sawit segar dan fermentasi tidak mempengaruhi berat badan akhir dan persentase karkas. Hasil pengukuran berat badan akhir secara berturut-turut adalah 123,$55 ; 122,34 ; 118,35 ; 122,24 ; 119,24 ; 124,72$; dan 121,95 g/ekor/35hari, persentase karkas secara berturut-turut adalah 65,$35 ; 64,68 ; 64,87 ; 65,20 ; 66,57 ; 65,36$; dan $64,87 \%$. Puyuh yang mendapatkan penambahan bungkil inti kelapa sawit fermentasi mengkonsumsi pakan lebih banyak $(P<0,05)$ dibandingkan puyuh yang mendapatkan pakan kontrol maupun pakan dengan suplementasi $10 \%$ BIKSF. Konversi pakan puyuh yang mendapatkan perlakuan pakan $10 \%$ BIKSF sama dengan konversi pakan kelompok kontrol, sedangkan puyuh dengan pakan perlakuan yang lain memiliki konversi pakan yang lebih tinggi $(P<0,05)$. Dapat disimpulkan bahwa penambahan pakan bungkil kelapa sawit maupun bungkil kelapa sawit yang difermentasi dengan isolate selulolitik belalang justru merugikan karena tidak mempengaruhi konversi pakan, namun justru menaikkan konsumsi pakan.

(Kata kunci: Bungkil inti kelapa sawit, Fermentasi, Penampilan produksi, Puyuh)

\section{ABSTRACT}

This research was conducted to examine the effects of fresh and fermented palm kernel cake (BIKS) supplementation in the diets on male japanese quail performance. Two hundred and ten day-old quails were randomly devided into seven treatment diets in three replications of ten quails each. The dietary treatments were: diet without palm kernel cake (control; K), control diets supplemented with $10 \%, 20 \%$, $30 \%$ BIKS (BIKS10\%, BIKS20\%, BIKS 30\%), control diets supplemented with $10 \%, 20 \%$, 30\% fermented palm kernel cake (BIKSF10\%, BIKSF20\%, BIKSF30\%). The collected data were final body weight, feed consumption, feed conversion, and carcass production. Data were statistically analyzed by ANOVA, followed by Duncan's New Multiple Range Test for any result with significant different. The results showed that dietary supplementation did not influence the final body weight and carcass production. The final body weight of the birds were 123.55, 122.34, 118.35, 122.24, 119.24, 124.72 and 121.95 g/head/35 day, carcass percentation were 65.35, 64.68, 64.87, 65.20, 66.57, 65.36, and 64.87\%. However, Japanese quails that given fermented palm kernel cake had higher feed consumption and conversion ratio, except for the birds with $10 \%$ BIKSF. It might be concluded that the additions of BIKSF in diet did not give beneficial effects on the performance of Japanese quail.

(Key words: Fermentation, Palm kernel cake, Performance, Quail)

\footnotetext{
${ }^{*}$ Korespondensi (corresponding author):

Telp. +62 81903713924 ,

E-mail: arif.pranata@mail.ugm.ac.id
} 


\section{Pendahuluan}

Berbagai cara telah dilakukan dalam rangka mencukupi kebutuhan protein hewani di Indonesia salah satunya adalah dengan memaksimalkan produksi ternak. Peningkatan produksi ternak dapat tercapai dengan adanya sinergi antara manajemen, genetik dari ternak yang akan dikembangkan serta kualitas pakan yang diberikan pada ternak Tingginya harga bahan baku pakan merupakan tantangan tersendiri bagi perusahaan peternakan khususnya peternakan unggas. Masih besarnya persaingan dalam mencukupi pangan dan pakan untuk ternak membuat sebagian besar bahan baku pakan didatangkan dari luar negeri. Hal tersebut membuat biaya produksi ternak semakin mahal.

Puyuh dikenal sebagai ternak yang dapat dimanfaatkan sebagai ternak penghasil telur dan daging bahkan ada sebagian orang yang memanfaatkan puyuh sebagai hewan kesayangan. Daging puyuh dapat dijadikan alternatif dalam mencukupi kebutuhan protein hewani selain produk ternak lainnya mengingat harga komoditas pangan hewani lainnya yang masih tidak menentu. Puyuh mempunyai karakteristik bobot dewasa mencapai $300 \mathrm{~g}$, dewasa kelamin dicapai pada saat berumur 42-48 hari, produksi telur mencapai 290 butir per tahun dengan Bobot telur berkisar antara 9 sampai $10 \mathrm{~g}$ serta proporsi karkas yang mencapai $78 \%$ (Mizutani, 2003).

Penggunaan bungkil inti kelapa sawit sebagai limbah pertanian dan perkebunan untuk bahan baku pakan ternak telah dilakukan untuk memperkecil biaya produksi ternak. Bungkil inti kalapa sawit memiliki potensi yang baik untuk dijadikan pakan ternak karena produksi kelapa sawit di Indonesia semakin meningkat. Saat ini luas perkebunan sawit di Indonesia mencapai sekitar 9,3 juta ha (Wiyono, 2013). Saat ini penggunaan bungkil inti kelapa sawit lebih banyak dipakai untuk ternak ruminansia mengingat kandungan serat kasarnya yang masih relatif tinggi. Penggunaan bungkil inti kelapa sawit sebagai bahan pakan unggas masih sangat terbatas karena kemampuan mencerna serat yang sangat terbatas. Ezieshi dan Olomu (2007) menyatakan bahwa kandungan serat kasar bungkil inti kelapa sawit berkisar antara $10-17 \%$ tergantung dari proses ekstraksi yang dilakukan untuk mendapatkan minyak kelapa sawit. Agar bisa digunakan sebagai bahan baku dalam pembuatan pakan unggas, diperlukan adanya tekhnologi untuk mengurangi kandungan serat dari bungkil inti kelapa sawit tersebut.

Fermentasi menggunakan isolat mikrobia fibrolitik terhadap berbagai bahan pakan dari hasil samping perkebunan telah terbukti dapat menurunkan kandungan serat kasar (Wizna et al., 2009). Gupta et al. (2011) menyatakan bahwa sumber bakteri penghasil enzim selulase yang paling potensial adalah dari bagian saluran pencernaan dari hewan yang mengonsumsi selulosa sebagai makanan utamanya. Bakteri selulolitik juga dapat ditemukan pada serangga seperti Isopteran dan Lepidoptera (Dillon dan Dillon, 2004) termasuk saluran pencernaan belalang (Idowu dan Edema, 2002).

Tujuan penelitian adalah untuk mengetahui pengaruh pemberian bungkil inti kelapa sawit yang difermentasi menggunakan isolat selulolitik dari belalang kembara terhadap penampilan produksi puyuh pedaging dan untuk mengetahui seberapa banyak bungkil inti kelapa sawit fermentasi dapat digunakan sebagai salah satu bahan penyusun ransum puyuh pedaging.

\section{Materi dan Metode}

\section{Materi}

Sebanyak 210 ekor day old quail (DOQ) dengan jenis kelamin jantan yang diperoleh dari PT Peksi Guna Raharja digunakan dalam penelitian ini. Ternak dimasukkan dalam kadang kelompok sebanyak 21 unit yang telah dilengkapi dengan tempat pakan dan air minum.

Isolat yang digunakan dalam penelitian ini adalah isolat bakteri selulolitik dari belalang yang telah dilakukan optimasi pertumbuhan pada riset sebelumnya (Pranata, 2014). Isolat ditumbuhkan pada media cair pada $\mathrm{pH} 5,5$ dan suhu $30^{\circ} \mathrm{C}$. Sampel saluran pencernaan belalang diambil dengan menggunakan peralatan yang sudah disterilkan menggunakan etanol $70 \%$.

Pakan disusun dengan bahan antara lain jagung kuning giling, bekatul, bungkil kedelai, tepung ikan, poultry meat meal, minyak kelapa sawit, premix, dicalcium phosphate, $\mathrm{CaCO}_{3}$, DL-Methionin dan LLysine $\mathrm{HCl}$. Susunan pakan perlakuan disajikan pada Tabel 1.

Bungkil inti kelapa sawit didapat dari distributor pakan ternak di Boyolali. Bungkil kelapa sawit fermentasi yang dipakai dalam 
penelitian ini merupakan bungkil kelapa sawit yang telah difermentasi dengan penambahan $30 \%$ isolat selulolitik dari total BIKS yang difermentasi dengan lama fermentasi selama 21 hari secara anaerob.

\section{Metode}

Saluran pencernaan yang telah didapat dimasukkan kedalam cawan petri dan dicuci kembali dengan aquades steril. Setelah bersih sampel dihomogenkan dalam aquades dengan perbandingan 1:1. Mikrobia dari sampel belalang diinokulasikan sebanyak $10 \%$ dari volume medium pengkayaan menurut Omelianski (1902) cit. Skinner (1971) dengan komposisi $0,2 \mathrm{~g}\left(\mathrm{NH}_{4}\right)_{2} \mathrm{SO}_{4}, 0,1$ $\mathrm{MgSO}_{4} .7 \mathrm{H}_{2} \mathrm{O}, 0,2 \mathrm{~g} \mathrm{~K}_{2} \mathrm{HPO}_{4}, 0,4 \mathrm{~g} \mathrm{CaCO}_{3}, 2$ $\mathrm{ml} \mathrm{NaCl} 1 \%, 2$ tetes resazurin $(0,1 \%), 120 \mathrm{ml}$ $\mathrm{H}_{2} \mathrm{O}$ dan $80 \mathrm{ml}$ larutan sampel. Sebagai substrat untuk mikrobia selulolitik ditambahkan selulosa sebanyak $2 \mathrm{~g}$ ke dalam medium.

Kadar air bahan yang difermentasi dibuat $40 \%$. BIKS sebanyak $5 \mathrm{~kg}$ diberi campuran inokulum mikrobia selulolitik sebanyak $30 \%$ dan dimasukkan dalam fermenter dengan kondisi anaerob, kemudian diinkubasi selama 21 hari pada suhu ruang.

Sebanyak 210 ekor DOQ dibagi menjadi tujuh perlakuan pakan yaitu tanpa pemberian BIKS atau BIKSF (kontrol), pemberian BIKS sebanyak 10\% (BIKS 10\%), pemberian BIKS sebanyak 20\% (BIKS 20\%), pemberian BIKS sebanyak 30\% (BIKS 30\%), pemberian BIKSF sebanyak 10\% (BIKSF $10 \%$ ), pemberian BIKSF sebanyak $20 \%$ (BIKSF 20\%) serta pemberian BIKSF sebanyak $30 \%$ (BIKSF 30\%) susunan ransum perlakuan disajikan pada Tabel 2. Setiap

Tabel 1. Bahan pakan yang digunakan saat penelitian (composition and nutritive value of experimental diets)

\begin{tabular}{|c|c|c|c|c|c|c|c|}
\hline $\begin{array}{l}\text { Bahan pakan (feed } \\
\text { composition) }\end{array}$ & $\begin{array}{c}\mathrm{PK}(\%) \\
(C P(\%))\end{array}$ & $\begin{array}{c}\text { Metabolisable } \\
\text { energy } \\
((\mathrm{kcal} / \mathrm{kg}))\end{array}$ & $\begin{array}{l}\text { SK (\%) } \\
(C F(\%))\end{array}$ & $\mathrm{Ca}(\%)$ & $\begin{array}{c}\text { P available } \\
(\%)\end{array}$ & $\begin{array}{c}\text { Lysin } \\
(\%)\end{array}$ & $\begin{array}{l}\text { Metionin } \\
(\%)\end{array}$ \\
\hline $\begin{array}{l}\text { Jagung kuning } \\
(\text { yellow corn })^{1} \\
\text { Bungkil kedelai }\end{array}$ & 8,5 & 3350 & 2,2 & 0,02 & 0,08 & 0,26 & 0,18 \\
\hline $\begin{array}{l}(\text { soy bean meal) } \\
\text { Poultry meat meal }\end{array}$ & 44 & 2230 & 3,3 & 0,29 & 0,65 & 2,96 & 0,67 \\
\hline $\begin{array}{l}(\mathrm{PMM})^{1} \\
\text { Tepung ikan (fish }\end{array}$ & 60 & 2950 & 1,5 & 0,33 & 0 & 3.1 & 0,99 \\
\hline$m e a l)^{1}$ & 63,6 & 2830 & 0,5 & 1,23 & 1,63 & 3,28 & 1 \\
\hline $\mathrm{BIKSF}^{2}$ & 20,62 & 1485 & 14,3 & 0,32 & 0,81 & 0 & 0 \\
\hline $\begin{array}{l}\text { BIKS }{ }^{2} \\
\text { Bekatul (rice }\end{array}$ & 26,53 & 1480 & 15,11 & 0,29 & 0,79 & 0 & 0 \\
\hline $\begin{array}{l}\text { bran })^{3} \\
\text { Minyak sawit }\end{array}$ & 12 & 2887 & 6,8 & 0,11 & 0,8 & 0,67 & 0,19 \\
\hline $\begin{array}{l}(\text { palm kernel oil) } \\
\text { Tepung batu } \\
\text { kapur (CaCO3) }\end{array}$ & 0 & 8600 & 0 & 0 & 0 & 0 & 0 \\
\hline$(\text { lime stone })^{1}$ & 0 & 0 & 0 & 39 & 0 & 0 & 0 \\
\hline Premix $(\mathrm{BTS})^{5}$ & 0 & 0 & 0 & 20,443 & 0 & 2,436 & 21,037 \\
\hline $\mathrm{NaCl}^{1}$ & 0 & 0 & 0 & 0 & 0 & 0 & 0 \\
\hline D-L Methionin ${ }^{6}$ & 58 & 0 & 0 & 0 & 0 & 0 & 99 \\
\hline $\begin{array}{l}\text { L-lisyne } \mathrm{HCl}^{6} \\
\text { Dikalsium Pospat }\end{array}$ & 95,6 & 0 & 0 & 0 & 0 & 88 & 0 \\
\hline$(\mathrm{Ca} 2 \mathrm{PO} 4)^{1}$ & 0 & 0 & 0 & 24 & 16,5 & 0 & 0 \\
\hline Filler (sand) ${ }^{1}$ & 0 & 0 & 0 & 0 & 0 & 0 & 0 \\
\hline
\end{tabular}

${ }^{1}$ NRC (1994)

${ }^{2}$ Pranata (2013)

${ }^{3}$ Hartadi et al. (2005)

${ }^{4}$ Anggorodi (1995)

${ }^{5}$ Premix mineral (lisyn 2,436\%, metionin 21,037\%, Ca 20,43\%, Na $31.05 \%$, dan $\mathrm{Cl} 2,7 \%$ ).

PK: protein kasar (crude protein), SK: serat kasar (crude fiber), Ca: calsium,

P: phosphor, BIKS: bungkil inti kelapa sawit tanpa fermentasi (unfermented palm kernel cake), BIKSF: bungkil inti kelapa sawit yang telah difermentasi (fermented palm kernel cake). 
perlakuan mendapat tiga kali ulangan. Proses pemeliharaan burung puyuh dilakukan selama 35 hari dimulai dari umur 14 hari. Pada setiap minggu dilakukan penimbangan berat badan dan konsumsi pakan. Data yang diamati meliputi konsumsi pakan, bobot badan,konversi pakan/feed conversion ratio (FCR) dan persentase karkas.

\section{Analisis data}

Penelitian dilakukan dengan menggunakan Rancangan Acak Lengkap Pola Searah dan dilanjutkan dengan uji beda mean Duncan's New Multiple Range Test untuk data yang berbeda nyata (Astuti, 2007), dengan bantuan software personal komputer Statistical Product and Service Solution (SPSS) versi 20.0.

\section{Hasil dan Pembahasan}

Rerata konsumsi pakan, pertambahan bobot badan, konversi pakan dan persentase karkas puyuh jantan yangdiberi bungkil inti kelapa sawit fermentasi dan non-fermentasi tersaji pada Tabel 4.

\section{Konsumsi pakan}

Hasil analisis statistik menunjukkan bahwa pemberian bungkil kelapa sawit fermentasi dan non-fermentasi dalam pakan meningkatkan konsumsi pakan puyuh. Pada Tabel 4 dapat dilihat bahwa perlakuan tanpa penambahan bungkil inti kelapa sawit memiliki konsumsi pakan yang paling rendah, yaitu 66,24 g/ekor/minggu sedangkan untuk penambahan bungkil inti sawit fermentasi dan

Tabel 2. Susunan bahan pakan yang digunakan dalam penelitian (experimental diets)

\begin{tabular}{|c|c|c|c|c|c|c|c|}
\hline \multirow{2}{*}{ Bahan pakan (feed composition) } & \multicolumn{7}{|c|}{ Perlakuan (treatments) } \\
\hline & 0 & NF 10 & NF 20 & NF 30 & F 10 & F 20 & F 30 \\
\hline Jagung kuning (yellow corn) & 30,75 & 30,75 & 30,75 & 31,00 & 30,75 & 30,75 & 31,00 \\
\hline $\begin{array}{l}\text { Bungkil kedelai (soy bean meal) } \\
\text { Tepung daging dan tulang (meat bone }\end{array}$ & 18,25 & 14,50 & 13,50 & 12,50 & 14,50 & 13,50 & 12,50 \\
\hline meal) & 6,25 & 6,25 & 6,25 & 6,25 & 6,25 & 6,25 & 6,25 \\
\hline Tepung ikan(fish meal) & 7,25 & 7,25 & 7,25 & 7,25 & 7,25 & 7,25 & 7,25 \\
\hline BIKS & 0,00 & 10,00 & 20,00 & 30,00 & 0,00 & 0,00 & 0,00 \\
\hline BIKSF & 0,00 & 0,00 & 0,00 & 0,00 & 10,00 & 20,00 & 30,00 \\
\hline Bekatul (rice bran) & 28,50 & 26,00 & 14,45 & 3,35 & 26,00 & 14,45 & 3,35 \\
\hline Minyak sawit (palm kernel oil) & 3,75 & 3,65 & 6,00 & 8,00 & 3,65 & 6,00 & 8,00 \\
\hline Tepung batu kapur (lime stone) (CaCO3) & 0,50 & 0,50 & 0,50 & 0,25 & 0,50 & 0,50 & 0,25 \\
\hline Premix (BTS) & 0,25 & 0,25 & 0,25 & 0,25 & 0,25 & 0,25 & 0,25 \\
\hline $\mathrm{NaCl}$ & 0,25 & 0,25 & 0,25 & 0,25 & 0,25 & 0,25 & 0,25 \\
\hline D-L Methionin & 0,15 & 0,15 & 0,25 & 0,25 & 0,15 & 0,25 & 0,25 \\
\hline L-lisyne $\mathrm{HCl}$ & 0,30 & 0,40 & 0,50 & 0,60 & 0,40 & 0,50 & 0,60 \\
\hline Dikalsium pospat (Ca2PO4) & 0.05 & 0.05 & 0.05 & 0.05 & 0.05 & 0.05 & 0.05 \\
\hline Filler (sand) & 3.75 & 0,00 & 0,00 & 0,00 & 0,00 & 0,00 & 0,00 \\
\hline Total & 100,00 & 100,00 & 100,00 & 100,00 & 100,00 & 100,00 & 100,00 \\
\hline $\begin{array}{l}\text { BIKS: bungkil inti kelapa sawit tanpa fermentasi } \\
\text { telah difermentasi (fermented palm kernel } \\
\text { NF 10: pemberian bungkil inti kelapa sawit non- } \\
\text { cake on diets). } \\
\text { NF 20: pemberian bungkil inti kelapa sawit non- } \\
\text { cake on diets). } \\
\text { NF 30: pemberian bungkil inti kelapa sawit non- } \\
\text { cake on diets). } \\
\text { F 10: pemberian bungkil inti kelapa sawit ferme } \\
\text { diets). } \\
\text { F 20: pemberian bungkil inti kelapa sawit ferme } \\
\text { diets). } \\
\text { F 30: pemberian bungkil inti kelapa sawit ferme }\end{array}$ & $\begin{array}{l}\text { nfermen } \\
k e) \text {. } \\
\text { rmentas } \\
\text { rmentas } \\
\text { rmentas } \\
\text { asi sebs } \\
\text { asi sebs }\end{array}$ & $\begin{array}{l}\text { ted palm k } \\
\text { si sebanyal } \\
\text { si sebanyal } \\
\text { si sebanyal } \\
\text { anyak } 10 \% \\
\text { anyak } 20 \%\end{array}$ & $\begin{array}{l}\text { rernel ca } \\
\text { k } 10 \% \text { (a } \\
20 \% \\
\text { k } 30 \% \\
\text { (additio } \\
\text { (additio }\end{array}$ & $\begin{array}{l}\text {, BIKSF } \\
\text { dition of } \\
\text { dition of } \\
\text { dition of } \\
\text { of } 10 \% \\
\text { of } 20 \%\end{array}$ & $\begin{array}{l}\% \text { unferm } \\
\% \text { unferm } \\
\% \text { unferm } \\
\text { mented } p \\
\text { mented } p\end{array}$ & $\begin{array}{l}\text { nented } p \\
\text { nented } p \\
\text { nented } p \\
\text { oalm ker } \\
\text { oalm ker }\end{array}$ & $\begin{array}{l}\text { m kernel } \\
\text { m kernel } \\
\text { m kernel } \\
\text { I cakeon } \\
\text { I cakeon }\end{array}$ \\
\hline
\end{tabular}


non-fermentasi secara berturut-turut adalah $68,50,77,00,80,08,73,88,80,43$, dan 82,62 g/ekor/minggu.

Konsumsi pakan puyuh yang mendapatkan pakan kontrol lebih rendah $(P<0,05)$ dibandingkan konsumsi pakan puyuh yang mendapatkan pakan dengan penambahan bungkil kelapa sawit fermentasi maupun penambahan bungkil inti kelapa sawit nonfermentasi. Berdasarkan Tabel 4 dengan makin banyaknya jumlah penambahan bungkil inti kelapa sawit fermentasi dan nonfermentasi maka konsumsi pakan puyuh semakin meningkat. Peningkatan konsumsi pakan ini disebabkan oleh kandungan serat kasar yang ikut meningkat dengan adanya penambahan bungkil inti kelapa sawit. Hal yang sama dilaporkan oleh Mateos et al. (2012) bahwa peningkatan jumlah serat pada pakan akan meningkatkan konsumsi pakan pada unggas.

Tidak terdapat perbedaan konsumsi pakan antara perlakuan fermentasi dan nonfermentasi. Konsumsi pakan dipengaruhi juga oleh ukuran partikel pakan. Alvarado et al. (2008) melaporkan bahwa adanya peningkatan jumlah serat kasar pada pakan dengan ukuran partikel yang sama tidak berpengaruh terhadap konsumsi pakan ayam broiler. Pada penelitian ini pakan yang diberikan tidak berbeda ukuran partikelnya walaupun dengan penambahan bungkil inti kelapa sawit yang difermentasi maupun tanpa fermentasi sampai dengan $30 \%$.

Serat pada pakan akan meningkatkan volume di dalam usus halus sehingga nutrien yang tersedia untuk unggas tidak tercerna dan terserap secara sempurna sebagai akibatnya puyuh akan lebih banyak makan untuk mencukupi kebutuhan nutriennya (Carre et al., 2002). Pada saat penelitian ini pakan diberikan secara ad libitum sehingga puyuh dapat terus makan sampai kebutuhannya tercukupi. Makinde (2012) juga menyatakan bahwa adanya serat dengan jumlah yang tinggi pada pakan unggas akan menyebabkan waktu lama tinggal pakan di saluran pencernaan akan semakin cepat dan akan menurunkan kecernaan protein kasar dan energi.

\section{Pertambahan bobot badan}

Hasil analisis statistik menunjukkan bahwa tidak terdapat pengaruh pemberian bungkil inti kelapa sawit fermentasi dan non fermentasi sampai level pemberian sebanyak $30 \%$ terhadap pertambahan bobot badan puyuh. Bobot badan puyuh masing-masing perlakuan berturut-turut adalah 123,55, $122,34,118,35,122,24,119,24,124,72$, dan 121,95 g/ekor/35 hari.

Ferket dan Gernat (2006) menyatakan bahwa pertambahan bobot tubuh juga dipengaruhi oleh konsumsi pakan. Jika

Tabel 3. Kandungan nutrisi pakan yang digunakan dalam penelitian (nutritive value on experimental diets)

\begin{tabular}{lrrrrrrr}
\hline \hline \multirow{2}{*}{$\begin{array}{c}\text { Nutrien (nutritive } \\
\text { value) }\end{array}$} & \multicolumn{1}{c}{ Perlakuan (treatments) } \\
\cline { 2 - 8 } & 0 & NF 10 & NF 20 & NF 30 & F 10 & F 20 & F 30 \\
\hline PK (CP) & 22,01 & 22,02 & 22,03 & 22,06 & 22,02 & 22,03 & 22,06 \\
Metabolisable energy & 2915,10 & 2906,00 & 2900,90 & 2900,00 & 2906,00 & 2900,90 & 2900,00 \\
SK (CF) & 3,45 & 5,79 & 7,62 & 9,49 & 5,19 & 6,43 & 7,71 \\
Ca & 1,17 & 1,10 & 1,12 & 1,04 & 1,10 & 1,12 & 1,04 \\
P & 0,85 & 0,85 & 0,84 & 0,82 & 0,85 & 0,84 & 0,82 \\
Metionin & 1,33 & 0,52 & 0,59 & 0,56 & 0,52 & 0,59 & 0,56 \\
Lysin & 0,55 & 1,31 & 1,35 & 1,39 & 1,31 & 1,35 & 1,39 \\
\hline PK: protein
\end{tabular}

PK: protein kasar (crudeprotein), SK: serat kasar (crudefiber), Ca: calsium, P: phosphor.

NF 10: pemberian bungkil inti kelapa sawit non-fermentasi sebanyak $10 \%$ (addition of $10 \%$ unfermented palm kernel cake on diets).

NF 20: pemberian bungkil inti kelapa sawit non-fermentasi sebanyak $20 \%$ (addition of $20 \%$ unfermented palm kernel cake on diets).

NF 30: pemberian bungkil inti kelapa sawit non-fermentasi sebanyak $30 \%$ (addition of $30 \%$ unfermented palm kernel cake on diets).

F 10: pemberian bungkil inti kelapa sawit fermentasi sebanyak $10 \%$ (addition of $10 \%$ fermented palm kernel cake on diets).

F 20: pemberian bungkil inti kelapa sawit fermentasi sebanyak $20 \%$ (addition of $20 \%$ fermented palm kernel cake on diets).

F 30: pemberian bungkil inti kelapa sawit fermentasi sebanyak 30\% (addition of 30\% fermented palm kernel cake on diets). 
Erener et al. (2003) menyatakan bahwa peningkatan jumlah serat kasar di dalam pakan karena penambahan hazelnut oil kernel meal menyebabkan peningkatan konversi pakan pada puyuh.

\section{Persentase karkas}

Hasil analisis statistik menunjukkan bahwa tidak terdapat pengaruh pemberian bungkil inti kelapa sawit fermentasi dan nonfermentasi sampai $30 \%$ di dalam ransum terhadap persentase karkas burung puyuh. Persentase karkas puyuh berdasarkan perlakuan K, F 10, F 20, F 30, NF 10, NF 20 dan NF 30 secara berturut-turut adalah 65,35 , $64,68,64,87,65,20,66,57,65,36$ dan $64,87 \%$.

Persentase karkas unggas dipengaruhi oleh genetik dan lingkungan, jenis kelamin dan umur (Husak et al., 2008). Sedangkan lingkungan sendiri dapat dibagi menjadi dua kategori yaitu fisiologi dan kandungan nutrisi dari pakan yang diberikan (Lesson, 2000). North dan Bell (1992) menyatakan bahwa berat karkas ayam dipengaruhi oleh berat hidup dari ayam yang disembelih. Pada penelitian ini tidak terdapat pengaruh pemberian bungkil inti kelapa sawit fermentasi dan non-fermentasi terhadap berat hidup puyuh sehingga persentase karkas puyuh juga menjadi berbeda tidak nyata.

Hasil penelitian ini bertolak belakang dengan penelitian yang dilakukan oleh Priabudiman dan Sukaryana (2010) yang menyatakan bahwa penggunaan campuran bungkil inti kelapa sawit dan bekatul fermentasi sampai $30 \%$ dalam pakan ayam broiler dapat meningkatkan persentase karkas. Hal yang sama juga dilaporkan oleh Cardosoa et al. (2010) bahwa puyuh yang mendapatkan pakan serealia yang tinggi kandungan seratnya akan berpengaruh terhadap persentase karkas yang dihasilkan.

\section{Kesimpulan}

Pemberian BIKSF dan BIKS tidak mempengaruhi berat badan puyuh dan persentase karkas. Pemberian BIKSF sebanyak 10, 20,30\% dan BIKS sebanyak $10,20,30 \%$ menyebabkan peningkatan konsumsi pakan sebesar $3,4 \%$ sampai $24,7 \%$ dan konversi pakan puyuh sebesar $9,4 \%$ sampai $18,1 \%$.

\section{Ucapan Terima Kasih}

Penghargaan yang sebesar-besarnya disampaikan kepada Prof. Lies Mira Yusiati dan Wihandoyo atas masukan dan saran dalam penulisan naskah ini.

\section{Daftar Pustaka}

Adama, T. Z., S. A. Ogunbajo and M. Mambo. 2007. Feed intake, growth performance, and nutrient digestibility of broiler chicks fed diets containing varying level of shorghum dried brewers grain. Int. J. Poult. Sci. 6: 592598.

Alvarado, J. M. G., E. J. Moreno, D. G. Valencia, R. Lazaro and G. G. Mateos. 2008. Effects of fiber source and heat processing of the cereal on the development and $\mathrm{pH}$ of the gastrointestinal tract of broilers fed diets based on corn or rice. J. Poult. Sci. 87: 1779-1795.

Anggorodi, R. 1995. Kemajuan Mutakhir dalam IImu Makanan Ternak Unggas. UI Press, Jakarta.

Astuti, M. 2007. Pengantar Ilmu Statistik untuk Peternakan dan Kesehatan Hewan. Cetakan Pertama. Binasti Publisher, Bogor.

Cardosoa, D., A. Z. M. Salem, F. D. Provenza, R. Rojo, L. M. Camacho and D. G. Satterlee. 2010. Cereal type in diet and housing system influences on growth performance and carcass yield in two Japanese quail genotypes. J. Anim. Feed Sci. Technol. 163: 52-58.

Carre, B., A. Idi, S. Maisonnier, J. P. Melcion, F. X. Oury, J. Gomez and P. Pluchard. 2002. Relationship between digestibilities of food components and characteristics of wheats (Triticum aestivum) introduced as the only cereal source in a broiler chicken diet. $\mathrm{Br}$. Poult. Sci. 43: 404-415.

Dillon, R. J. and V. M. Dillon. 2004. The gut bacteria of insects non-pathogenic interaction. Annual Review of Entomology. 49: 71-92.

Erener, G., A. Ozer and N. Ocak. 2003. Growth and laying performance of japanese quail fed graded levels of hazelnut kernel oil meal incorporated into diets. Asian-Aust. J. Anim. Sci. 16: 1789-1794. 
Ezieshi, E. V. and J. M. Olomu. 2007. Nutritional Evaluation of Palm Kernel Meal Type: 1. Proximat composition and metabolizable energy value. Departement of Animal Science, University of Bevin, Nigeria.

Ferket, P. R. and A. G. Gernat. 2006. Factors that affect feed intake of meat birds: a review. Int. J. Poult. Sci. 5: 905-911.

Gupta, P., K. Samant and A. Sahu. 2011. Isolation of cellulose-degrading bacteria and determination of their cellulolytic potential. Int. J. Microbiol. 8: 1-12.

Hartadi, H., S, Reksohadiprojo, dan A. D. Tillman. 2005. Tabel Komposisi Bahan Pakan untuk Indonesia. Gadjah Mada Press, Yogyakarta.

Husak, R. L., J. G. Sebranek and K. Bregendahl. 2008. A survey of commercially available broilers marketed as organic, free-range, and conventional broilers forcooked meat yields, meat composition, and relative value. J. Poult. Sci. 87: 2367-2376.

Idowu, A. B. and O. A. Edema. 2002. The microbial flora of the different gut regions of the variegated grasshopper Zonocerus variegatus L Orthoptera : Pyrgomorphidae. Niger. J. PL. Prot. 20: 19-30.

Lesson, S. 2000. Nutrition and Quality of Broiler Carcass. Departement of Animal and Poultry Science, University of Guelph, Ontario.

Makinde, O. J. 2012. Comparative response of japanese quails fed palm kernel meal and brewer's dried grain based diets supplemented with maxigrain enzyme. Thesis. Department of Animal Science, Ahmadu Bello University, Zaria.

Mateos, G. G., E. Jimenez-Moreno, M. P. Serrano and R. P. Lazaro. 2012. Poultry response to high levels of dietary fiber sources varying in physical and chemical characteristics. J. Appl. Poult. 21: 156-174.
Mizutani, M. 2003. The Japanese Quail. Laboratory Animal Research Station, Nippon Institute for Biological Science, Kobuchizawa, Yamanashi.

NRC. 1994. Nutrient Requirements of Poultry. $9^{\text {th }}$ edn. National Academy Press, Washington D.C.

Pranata, A. 2014. Pengaruh fermentasi bungkil inti kelapa sawit menggunakan isolate bakteri selulolitik dari belalang kembara (Lokusta Migratoria L) terhadap penampilan produksi puyuh pedaging. Tesis Fakultas Peternakan, Universitas Gadjah Mada, Yogyakarta.

Priabudiman, Y. and Y. Sukaryana. 2010. The influence of palm kernel cake and rice bran fermentation product mixture to the broiler carcass quality. Int. J. Sci. Eng. 2: 1-3.

Skrobanek, P., M. Hrbata, M. Baranovska and M. Jurani. 2004. Growth of japanese quail chicks in simulated weightlessness. Acta Vet. Brno 73: 157-164.

Simol, C. F., A. A. Tuen, H. H. A. Khan, J. K. Chubo, P. J. H. King and K. H. Ong. 2012. Performance of chicken broilers fed with diets substituted with mulberry leaf powder. African J. Biotech. 11: 16106-16111.

Willis, J. D., W. E. Klingeman, C. Oppert, B. Oppert and J. L. Jurat-Fuentes. 2010. Characterization of cellulolytic activity from digestivefluids of dissosteira carolina (Orthoptera: Acrididae). Comp. Biochem. Physiol. 17: 267-272.

Wiyono. 2013. Swasta Baru: Sawit hanya boleh Kuasai Lahan 100 ribu ha. Info Sawit. Vol VII, hal. 12.

Wizna, H. Abbas, Y. Rizal, A. Dharma and I. P. Kompiang. 2009. Improving the quality of tapioca by-products (onggok) as poultry feedthrough fermentation by Bacillus amyloliquefaciens. Pakistan J. Nutr. 8: 1636-1640. 